\title{
Synthesis, Structural Characterization, and Antibacterial Activity of Novel Erbium(III) Complex Containing Antimony
}

\author{
Ting Liu $\mathbb{D}$, Rong-Gui Yang, and Guo-Qing Zhong $\mathbb{B}$ \\ School of Material Science and Engineering, Southwest University of Science and Technology, Mianyang 621010, China \\ Correspondence should be addressed to Guo-Qing Zhong; zgq316@163.com
}

Received 22 December 2017; Accepted 29 January 2018; Published 20 March 2018

Academic Editor: Konstantinos Tsipis

Copyright ( 2018 Ting Liu et al. This is an open access article distributed under the Creative Commons Attribution License, which permits unrestricted use, distribution, and reproduction in any medium, provided the original work is properly cited.

\begin{abstract}
The novel 3D edta-linked heterometallic complex $\left[\mathrm{Sb}_{2} \mathrm{Er}(\text { edta })_{2}\left(\mathrm{H}_{2} \mathrm{O}\right)_{4}\right] \mathrm{NO}_{3} \cdot 4 \mathrm{H}_{2} \mathrm{O}\left(\mathrm{H}_{4}\right.$ edta $=$ ethylenediaminetetraacetic acid $)$ was synthesized and characterized by elemental analyses, single-crystal X-ray diffraction, powder X-ray diffraction (XRD), Fourier transform infrared spectroscopy (FTIR), and thermal analysis. The complex crystallizes in the monoclinic system with space group $\mathrm{Pm}$. In the complex, each erbium(III) ion is connected with antimony(III) ions bridging by four carboxylic oxygen atoms, and in each $[\mathrm{Sb}(\mathrm{edta})]^{-}$anion, the antimony(III) ion is hexacoordinated by two nitrogen atoms and four oxygen atoms from the edta ${ }^{4-}$ ions, together with a lone electron pair at the equatorial position. The erbium(III) ion is octacoordinated by four oxygen atoms from four different edta ${ }^{4-}$ ions and four oxygen atoms from the coordinated water molecules. The carboxylate bridges between antimony and erbium atoms form a planar array, parallel to the $\left(\begin{array}{lll}1 & 0 & 0\end{array}\right)$ plane. There is an obvious weak interaction between antimony atom and oxygen atom of the carboxyl group from the adjacent layer. The degradation of the complex proceeds in several steps and the water molecules and ligands are successively emitted, and the residues of the thermal decomposition are antimonous oxide and erbium(III) oxide. The complex was evaluated for its antimicrobial activities by agar diffusion method, and it has good activities against the test bacterial organisms.
\end{abstract}

\section{Introduction}

Much attention is currently focused on the rational design and controlled synthesis of metal-organic complexes with novel topological structure because of various potential applications of these complexes as function materials, catalysts, and medicaments [1-5]. Metal-based drugs continue to play a very important role in clinical medicine, and antimonybased metallotherapeutic drugs were used in medical applications very early in the past. Nowadays many of antimony (III) complexes have been clinically used because of their biological activities and drug efficacies [6-19], such as the treatment of a variety of microbial infections including leishmaniasis, parasitic diseases, diarrhea, peptic ulcers, helicobacter pylori, and so forth. More recently, the use of antimony complexes in cancer chemotherapy has become a topic of interest, and antimony(III) compounds have been tested in vitro for their cytotoxic effects on the proliferation of some leukemia and solid tumor cells [20-26].
The aminopolycarboxylate ligands can act as multidentate ligand, and their important characteristic bases on the bridging mode of the carboxylate groups [27-31]. Among the investigation of syntheses and structures of various aminopolycarboxylate complexes, heterometallic complexes are of great interest in view of their fascinating structural diversity and potential applications. Some edtalinked heterometallic complexes containing transition metals have been synthesized and structurally characterized $\left(\mathrm{H}_{4}\right.$ edta $=$ ethylenediaminetetraacetic acid $)[32,33]$. However, less work on the main group elements participating in the heterometallic complexes due to the particularities of main group elements has been reported [34-40]. Antimony compounds are easy to be hydrolyzed in aqueous solutions, which makes difficult to synthesize their complexes [23], so the study of antimony complexes is much less than that of transition metal and rare earth metal complexes.

In continuation of our interest on the antimony(III) [41-43] and bismuth(III) $[44,45]$ complexes with aminopolycarboxylate 
ligands, we report herein a novel antimony-based heterometallic complex $\left[\mathrm{Sb}_{2}(\mathrm{edta})_{2}-\mu_{4}-\mathrm{Er}\left(\mathrm{H}_{2} \mathrm{O}\right)_{4}\right] \mathrm{NO}_{3} \cdot 4 \mathrm{H}_{2} \mathrm{O}$; its composition and crystal structure have been characterized by elemental analyses, FTIR spectrum, single crystal X-ray diffraction, and thermal analysis. The complex has been evaluated for its antimicrobial activities by agar diffusion method. The synthesis method for the complexes of the antimony-transition metal and antimony-lanthanide with aminopolycarboxylic acid ligands is different. Significant knowledge about these complexes is very interesting due to their fascinatingly special structures and interesting properties, and antimony ion has weaker coordination ability than transition metal or lanthanide series ions leading to fewer reports about its complexes. The structural variety of antimony complexes is not similar to bismuth complexes. Bismuth(III) displays a marked propensity to form the complexes with high coordination number, such as the coordination number of 6-10 [32]. However, antimony(III) is generally hexacoordinated, and the stereochemistry of antimony(III) complexes is usually based on a distorted trigonal bipyramid with a pair of active lone electrons in one of the trigonal planar sites. The lone pair electrons located on antimony atom plays an important role in the final geometry obtained [23].

\section{Experimental Section}

2.1. Materials and Physical Measurements. All chemicals purchased in the experiments were of analytical reagent and used as received without further purification, and the solvents were also commercially available and further purified before use. The antimony trichloride, erbium nitrate hexahydrate, ethylenediaminetetraacetic acid, and ammonium bicarbonate were purchased from Sinopharm Chemical Reagent Co. Ltd. of Shanghai. The complex $[\mathrm{Sb}(\mathrm{Hedta})] \cdot 2 \mathrm{H}_{2} \mathrm{O}$ was synthesized as described in the literature [46]. Staphylococcus aureus, Escherichia coli, Salmonella typhi, Bacillus subtilis, and Staphylococcus epidermidis were provided by the 404 hospital of Sichuan Mianyang.

Elemental analyses of $\mathrm{C}, \mathrm{H}$, and $\mathrm{N}$ were performed on an elemental analysis service of vario EL III elemental analyzer. Melting point was determined in capillary tubes on an X4 melting point apparatus. Molar conductance was measured by a DDS-11A conductometer. XRD pattern was recorded on a $\mathrm{D} / \mathrm{max}$-II X-ray diffractometer in the diffraction angle range of $5-80^{\circ}$. FTIR spectrum was measured with a $\mathrm{KBr}$ disk on a Nicolet 570 FT-IR system. Thermal gravimetric (TG) analysis was carried out on a STA 449C differential thermal balance in air, with a heating rate of $10^{\circ} \mathrm{C} \cdot \mathrm{min}^{-1}$ and $\alpha-\mathrm{Al}_{2} \mathrm{O}_{3}$ reference.

2.2. Synthesis of $\left[\mathrm{Sb}_{2} \mathrm{Er}(\mathrm{edta})_{2}\left(\mathrm{H}_{2} \mathrm{O}\right)_{4}\right] \mathrm{NO}_{3} \cdot 4 \mathrm{H}_{2} \mathrm{O} .2 \mathrm{mmol}$ $(0.90 \mathrm{~g})$ of $[\mathrm{Sb}(\mathrm{Hedta})] \cdot 2 \mathrm{H}_{2} \mathrm{O}$ was dissolved in $60 \mathrm{~mL}$ hot distilled water, and the solution was heated to $95^{\circ} \mathrm{C}$. Then, $2 \mathrm{mmol}(0.16 \mathrm{~g}) \mathrm{NH}_{4} \mathrm{HCO}_{3}$ was gradually added to the above solution, and the solution was stirred for about $30 \mathrm{~min}$. After cooling the solution to room temperature, $2 \mathrm{mmol}(0.92 \mathrm{~g})$ $\mathrm{Er}\left(\mathrm{NO}_{3}\right)_{3} \cdot 6 \mathrm{H}_{2} \mathrm{O}$ was added to the above solution; in this case, the transparent solution was obtained. The mixture solution was held for a week, and the pink block crystals were isolated from the solution. The yield was about $58 \%$. m. p.: $192^{\circ} \mathrm{C}$ (decomposition). Anal. Calc. for the complex $\mathrm{C}_{20} \mathrm{H}_{40} \mathrm{~N}_{5} \mathrm{O}_{27} \mathrm{ErSb}_{2}$ : C, 20.13; H, 3.38; N, 5.87\%. Found: C, 20.01; H, 3.22; N, 5.51\%. FTIR (KBr disk): 3426(s), 2986(w), 2956(w), 1654(s), 1593(s), 1508(w), 1469(m), 1448(m), 1402 (w), 1385(m), 1356(m), 1317(m), 1294(m), 1254(m), 1158(m), 1082(m), 1039(m), 1000(m), 948(m), 916(m), 864(m), 828 (m), 741(w), 710(m), 661(m), 619(w), 594(w), 562(m), 529 (m), 516(w), 460(m), 448(m), 434(m), 426(m), 420(m), and $407(\mathrm{~m}) \mathrm{cm}^{-1}$.

2.3. X-Ray Cystallography. All measurements were made on a Siemens P4 diffractometer at 289(2) K using graphite monochromated Mo $\mathrm{K}_{\alpha}(\lambda=0.71073 \AA)$. A pink block with dimensions $0.48 \times 0.44 \times 0.20 \mathrm{~mm}^{3}$ was mounted on a glass fiber. Diffraction data were collected in $\omega$ mode in the range $1.84^{\circ}<\theta<26.00^{\circ}$. Data were corrected for Lorentz and polarization effects, and an empirical absorption correction was applied. The structures were solved by the SHELXS-97 program and refined using full-matrix least squares on $F^{2}$ with the SHELXL-97 program [47]. For the complex, the hydrogen atoms attached to the oxygen atoms of water molecules were not located from the difference Fourier map due to the effect of heavy erbium and antimony atoms, while other nonhydrogen atoms were refined anisotropically, and hydrogen atoms were introduced at the calculated positions. CCDC 637089 contains the supplementary crystallographic data for the title complex. These data can be obtained free of charge via http://www.ccdc.cam.ac.uk/conts/retrieving.html or from the Cambridge Crystallographic Data Centre, 12 Union Road, Cambridge CB2 1EZ, UK; fax: (+44) 1223-336033 or e-mail: deposit@ccdc.cam.ac.uk.

\section{Results and Discussion}

The complex is stable in air and soluble in hot water and difficult to dissolve in most common organic solvents and slightly soluble in DMF. The molar conductance values of the complex in DMF and deionized water $\left(10^{-3} \mathrm{~mol} \cdot \mathrm{L}^{-1}\right.$ solution at $25^{\circ} \mathrm{C}$ ) are 88.2 and $92.5 \mathrm{~S} \cdot \mathrm{cm}^{2} \cdot \mathrm{mol}^{-1}$, respectively. The results show that the complex belongs to $1: 1$ electrolyte nature [48].

3.1. Crystal Structure Analysis. The molecular structure of the title complex with atomic labeling scheme is shown in Figure 1. Crystallographic data and structure refinement parameters of the complex are given in Table 1, and selected bond lengths and bond angles are given in Table 2. The asymmetric unit of the complex consists of a crystallographically independent heterometallic motif $\left[\mathrm{Sb}_{2}-\mu_{4}-\right.$ (edta) $\left.{ }_{2} \mathrm{Er}\left(\mathrm{H}_{2} \mathrm{O}\right)_{4}\right]^{+}$, nitrate counterion, and four free water molecules. Each edta ${ }^{4-}$ ion consists of carboxylate groups adopting monodentate mode coordination to the antimony ion and bidentate bridging over one erbium ion and two different antimony ions. Each erbium(III) ion has a distorted trigonal dodecahedron environment with an $\mathrm{O}_{8}$ donor atom 


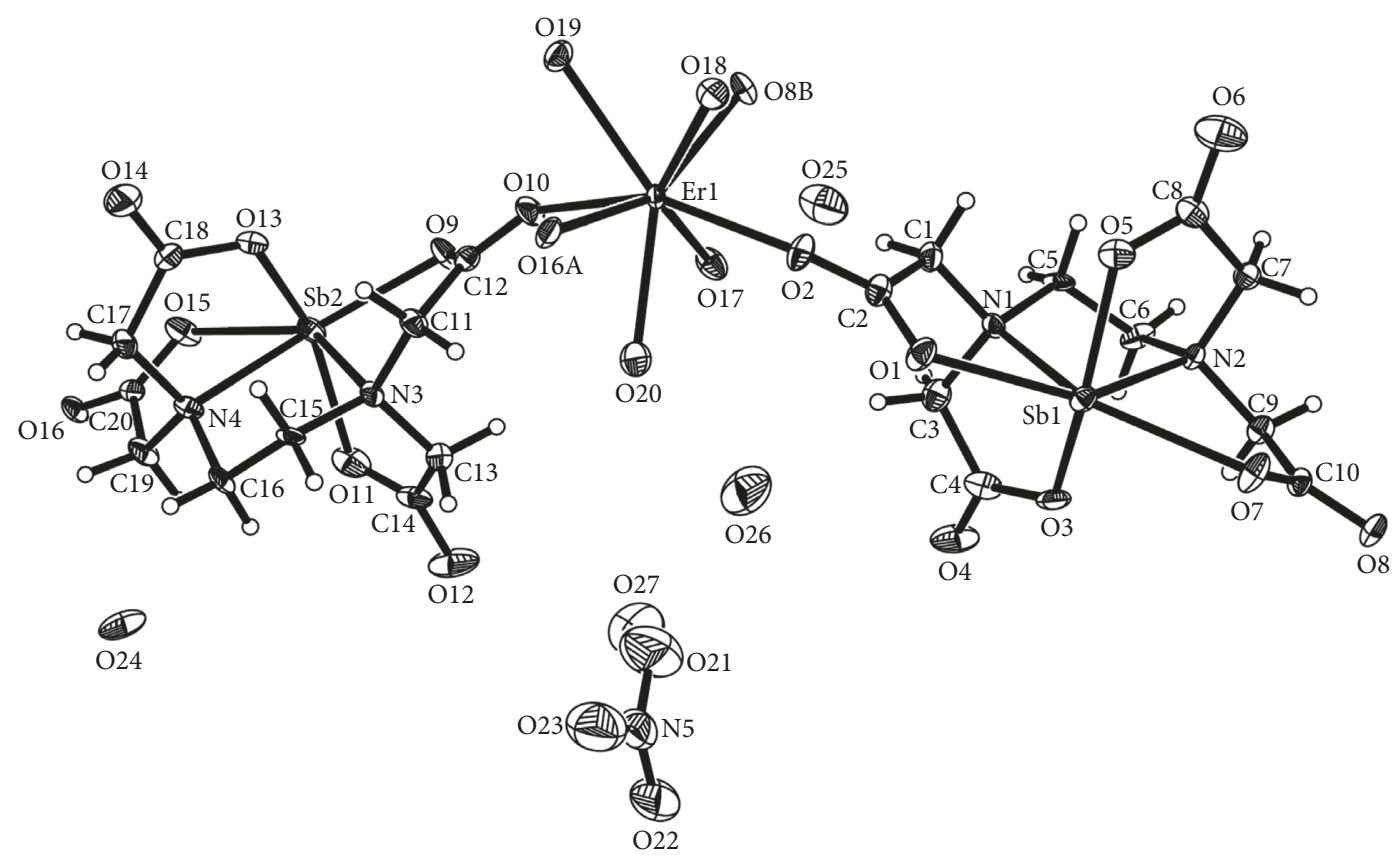

Figure 1: Thermal ellipsoid representation (at 50\% probability) of molecular structure unit of the complex. All the $\mathrm{H}$ atoms are omitted for clarity. Symmetry codes: A $x-1 / 2,-y, z-1 / 2$; B $x+1 / 2,-y+1, z-1 / 2$.

TABLE 1: Crystallographic data and structure refinement parameters of the title complex.

\begin{tabular}{lccc}
\hline Empirical formula & $\mathrm{C}_{20} \mathrm{H}_{40} \mathrm{~N}_{5} \mathrm{O}_{27} \mathrm{ErSb}_{2}$ & $D_{\text {calc }}\left(\mathrm{g} \cdot \mathrm{cm}^{-3}\right)$ & 2.278 \\
Formula weight $\left(\mathrm{g} \cdot \mathrm{mol}^{-1}\right)$ & 1193.33 & Absorption coefficient $\left(\mathrm{mm}^{-1}\right)$ & 4.043 \\
$T(\mathrm{~K})$ & $289(2)$ & $F(000)$ & 1162 \\
Crystal system & Monoclinic & Crystal size $\left(\mathrm{mm}^{3}\right)$ & $0.48 \times 0.44 \times 0.20$ \\
Space group & $P m$ & Theta range for data collection $\left(^{\circ}\right)$ & 1.84 to 26.00 \\
$a(\AA)$ & $7.3790(10)$ & Limiting indices & $-9 \leq h \leq 9,-27 \leq k \leq 27,-13 \leq l \leq 13$ \\
$b(\AA)$ & $22.116(5)$ & Reflections collected/unique & $7847 / 6826[R(\mathrm{int})=0.0209]$ \\
$c(\AA)$ & $10.661(3)$ & Goodness-of-fit $(\mathrm{GOF})$ on $F^{2}$ & 1.002 \\
$\beta\left({ }^{\circ}\right)$ & $90.55(2)$ & Final $R$ indices $[I>2 \sigma(I)]$ & $R_{1}=0.0392, w R_{2}=0.1051$ \\
$V\left(\AA^{3}\right)$ & $1739.7(7)$ & $R$ indices (all data) & $R_{1}=0.0416, w R_{2}=0.1062$ \\
$Z$ & 2 & Largest diff. peak and hole $\left(\mathrm{e} \cdot \AA^{-3}\right)$ & 1.767 and -1.676
\end{tabular}

array: four bridged oxygen atoms $[\mu-\mathrm{O}(2), \mu-\mathrm{O}(10), \mu-\mathrm{O}(8 \mathrm{~B})$, and $\mu-\mathrm{O}(16 \mathrm{~A})]$ from four edta ${ }^{4-}$ ligands with $\mathrm{Er}-\mathrm{O}$ bond distances ranging from $2.285(7)$ to $2.298(7) \AA$, four oxygen atoms from the four coordinated water molecules with $\mathrm{Er}-\mathrm{O}$ bond distances ranging from 2.347 (9) to 2.432(7) $\AA$, and the coordination structure of the erbium(III) is shown in Figure 2. The antimony(III) ion is hexacoordinated by four oxygen atoms and two nitrogen atoms from the edta ${ }^{4-}$ ligand, and the lone pair electrons on the antimony atom cause the coordination geometry to be distorted octahedron with two oxygen atoms $[\mathrm{O}(3)$ and $\mathrm{O}(5)]$ at the axial sites. Two oxygen $[\mathrm{O}(1)$ and $\mathrm{O}(7)]$ and two nitrogen $[\mathrm{N}(1)$ and $\mathrm{N}(2)]$ atoms occupy the equatorial plane. The sum of the equatorial bond angles $\mathrm{O}(1)-\mathrm{Sb}(1)-\mathrm{O}(7), \mathrm{N}(1)-\mathrm{Sb}(1)-\mathrm{N}(2), \mathrm{N}(1)-\mathrm{Sb}(1)-\mathrm{O}(1)$, and $\mathrm{N}(2)-\mathrm{Sb}(1)-\mathrm{O}(7)$ is $361^{\circ}$, which shows that the $\mathrm{O}(1), \mathrm{O}(7)$, $\mathrm{N}(1), \mathrm{N}(2)$, and $\mathrm{Sb}$ atoms are almost located at one plane. The bond angle $\mathrm{O}(3)-\mathrm{Sb}(1)-\mathrm{O}(5)$ of $146.1^{\circ}$ is almost twice as large as the bond angle $\mathrm{N}(1)-\mathrm{Sb}(1)-\mathrm{N}(2)\left(77.0^{\circ}\right)$ or $\mathrm{N}(2)-\mathrm{Sb}$ (1) $-\mathrm{O}(7)\left(67.0^{\circ}\right)$, which may be due to the existence of a lone pair of electron in the diad direction [49]. The distances of the $\mathrm{Sb}-\mathrm{O}$ bonds are in the range of $2.127(8)$ to $2.541(8) \AA$, while the $\mathrm{Sb}-\mathrm{N}$ bond lengths are in the range of 2.315(8) to $2.332(8) \AA$. The distances of the bidentate chelating bonds $\mathrm{Sb}(1)-\mathrm{O}(1)(2.459 \AA)$ and $\mathrm{Sb}(1)-\mathrm{O}(7)(2.564 \AA)$ are longer than the monodentate bond distances [ $\mathrm{Sb}(1)-\mathrm{O}(3)(2.215 \AA)$ and $\mathrm{Sb}(1)-\mathrm{O}(5)(2.127 \AA)]$. The $\mathrm{O}-\mathrm{Sb}-\mathrm{O}$ bond angles lie between $80.4(3)^{\circ}$ and $148.3(3)^{\circ}$. These bonds and angles are slightly longer and wider, respectively, than those in the complex $\left[\mathrm{CaSb}_{2}(\text { edta })\left(\mathrm{H}_{2} \mathrm{O}\right)_{8}\right]_{n}[49]$. These bond distances and angles (Table 2) are consistent with those of other edta-Sb compounds [50].

The carboxylate bridges between antimony and erbium atoms $[\mathrm{O}(1)-\mathrm{C}(2)-\mathrm{O}(2)$ and $\mathrm{O}(7)-\mathrm{C}(10)-\mathrm{O}(8)]$ form a planar array of metal atoms, with a maximum deviation of $0.416 \AA$, parallel to the $\left(\begin{array}{lll}1 & 0 & 0\end{array}\right)$ plane (Figure 3$)$. Furthermore, there is an obvious weak interaction between antimony atom and oxygen atom of the carboxyl group from the adjacent layer. The interaction makes the layers extend to an infinite three-dimensional framework (Figure 4). Hydrogen bonds and short van der Waals force contact between oxygen atoms 
TABLE 2: Selected bond lengths $(\AA)$ and angles $\left({ }^{\circ}\right)$ of the title complex.

\begin{tabular}{|c|c|c|c|}
\hline $\operatorname{Er}(1)-O(16) \# 1$ & $2.285(7)$ & $\operatorname{Er}(1)-\mathrm{O}(10)$ & $2.290(7)$ \\
\hline $\mathrm{Er}(1)-\mathrm{O}(2)$ & $2.290(7)$ & $\operatorname{Er}(1)-O(8) \# 2$ & $2.298(7)$ \\
\hline $\operatorname{Er}(1)-O(20)$ & $2.347(9)$ & $\operatorname{Er}(1)-O(17)$ & $2.375(8)$ \\
\hline $\mathrm{Er}(1)-\mathrm{O}(19)$ & $2.421(7)$ & $\mathrm{Er}(1)-\mathrm{O}(18)$ & $2.432(7)$ \\
\hline $\mathrm{Sb}(1)-\mathrm{O}(5)$ & $2.127(8)$ & $\mathrm{Sb}(1)-\mathrm{O}(3)$ & $2.215(8)$ \\
\hline $\mathrm{Sb}(1)-\mathrm{N}(1)$ & $2.315(8)$ & $\mathrm{Sb}(1)-\mathrm{N}(2)$ & $2.332(8)$ \\
\hline $\mathrm{Sb}(1)-\mathrm{O}(1)$ & $2.459(7)$ & $\mathrm{Sb}(1)-\mathrm{O}(7)$ & $2.564(7)$ \\
\hline $\mathrm{Sb}(2)-\mathrm{O}(13)$ & $2.124(8)$ & $\mathrm{Sb}(2)-\mathrm{O}(11)$ & $2.218(9)$ \\
\hline $\mathrm{Sb}(2)-\mathrm{N}(3)$ & $2.318(8)$ & $\mathrm{Sb}(2)-\mathrm{N}(4)$ & $2.322(8)$ \\
\hline $\mathrm{Sb}(2)-\mathrm{O}(9)$ & $2.438(7)$ & $\mathrm{Sb}(2)-\mathrm{O}(15)$ & $2.541(8)$ \\
\hline $\mathrm{O}(16) \# 1-\mathrm{Er}(1)-\mathrm{O}(10)$ & $85.6(3)$ & $\mathrm{O}(16) \# 1-\operatorname{Er}(1)-\mathrm{O}(2)$ & $102.7(3)$ \\
\hline $\mathrm{O}(10)-\mathrm{Er}(1)-\mathrm{O}(2)$ & $150.5(3)$ & $\mathrm{O}(16) \# 1-\mathrm{Er}(1)-\mathrm{O}(8) \# 2$ & $148.0(3)$ \\
\hline $\mathrm{O}(10)-\mathrm{Er}(1)-\mathrm{O}(8) \# 2$ & $102.5(3)$ & $\mathrm{O}(2)-\operatorname{Er}(1)-\mathrm{O}(8) \# 2$ & $85.4(3)$ \\
\hline $\mathrm{O}(16) \# 1-\mathrm{Er}(1)-\mathrm{O}(20)$ & $70.8(3)$ & $\mathrm{O}(10)-\mathrm{Er}(1)-\mathrm{O}(20)$ & $80.9(3)$ \\
\hline $\mathrm{O}(2)-\mathrm{Er}(1)-\mathrm{O}(20)$ & $75.5(3)$ & $\mathrm{O}(8) \# 2-\mathrm{Er}(1)-\mathrm{O}(20)$ & $140.7(3)$ \\
\hline $\mathrm{O}(16) \# 1-\mathrm{Er}(1)-\mathrm{O}(17)$ & $138.7(3)$ & $\mathrm{O}(10)-\mathrm{Er}(1)-\mathrm{O}(17)$ & $74.5(3)$ \\
\hline $\mathrm{O}(2)-\operatorname{Er}(1)-\mathrm{O}(17)$ & 81.1(3) & $\mathrm{O}(8) \# 2-\mathrm{Er}(1)-\mathrm{O}(17)$ & $72.8(3)$ \\
\hline $\mathrm{O}(20)-\mathrm{Er}(1)-\mathrm{O}(17)$ & $70.5(3)$ & $\mathrm{O}(16) \# 1-\mathrm{Er}(1)-\mathrm{O}(19)$ & $78.6(2)$ \\
\hline $\mathrm{O}(10)-\operatorname{Er}(1)-\mathrm{O}(19)$ & $69.4(3)$ & $\mathrm{O}(2)-\operatorname{Er}(1)-\mathrm{O}(19)$ & $139.7(3)$ \\
\hline $\mathrm{O}(8) \# 2-\mathrm{Er}(1)-\mathrm{O}(19)$ & $75.6(3)$ & $\mathrm{O}(20)-\mathrm{Er}(1)-\mathrm{O}(19)$ & $138.7(3)$ \\
\hline $\mathrm{O}(17)-\mathrm{Er}(1)-\mathrm{O}(19)$ & $124.6(3)$ & $\mathrm{O}(16) \# 1-\mathrm{Er}(1)-\mathrm{O}(18)$ & $76.3(3)$ \\
\hline $\mathrm{O}(10)-\mathrm{Er}(1)-\mathrm{O}(18)$ & $139.0(3)$ & $\mathrm{O}(2)-\operatorname{Er}(1)-\mathrm{O}(18)$ & $70.2(3)$ \\
\hline $\mathrm{O}(8) \# 2-\mathrm{Er}(1)-\mathrm{O}(18)$ & $77.6(3)$ & $\mathrm{O}(20)-\mathrm{Er}(1)-\mathrm{O}(18)$ & $125.0(3)$ \\
\hline $\mathrm{O}(17)-\operatorname{Er}(1)-\mathrm{O}(18)$ & $140.0(3)$ & $\mathrm{O}(19)-\mathrm{Er}(1)-\mathrm{O}(18)$ & 71.1(3) \\
\hline $\mathrm{O}(5)-\mathrm{Sb}(1)-\mathrm{O}(3)$ & $146.1(3)$ & $\mathrm{O}(5)-\mathrm{Sb}(1)-\mathrm{N}(1)$ & $79.4(3)$ \\
\hline $\mathrm{O}(3)-\mathrm{Sb}(1)-\mathrm{N}(1)$ & $73.3(3)$ & $\mathrm{O}(5)-\mathrm{Sb}(1)-\mathrm{N}(2)$ & $75.4(3)$ \\
\hline $\mathrm{O}(3)-\mathrm{Sb}(1)-\mathrm{N}(2)$ & $79.2(3)$ & $\mathrm{N}(1)-\mathrm{Sb}(1)-\mathrm{N}(2)$ & $77.0(3)$ \\
\hline $\mathrm{O}(5)-\mathrm{Sb}(1)-\mathrm{O}(1)$ & $82.5(3)$ & $\mathrm{O}(3)-\mathrm{Sb}(1)-\mathrm{O}(1)$ & $105.2(3)$ \\
\hline $\mathrm{N}(1)-\mathrm{Sb}(1)-\mathrm{O}(1)$ & $68.7(3)$ & $\mathrm{N}(2)-\mathrm{Sb}(1)-\mathrm{O}(1)$ & $142.0(3)$ \\
\hline $\mathrm{O}(5)-\mathrm{Sb}(1)-\mathrm{O}(7)$ & $99.1(3)$ & $\mathrm{O}(3)-\mathrm{Sb}(1)-\mathrm{O}(7)$ & $91.1(3)$ \\
\hline $\mathrm{N}(1)-\mathrm{Sb}(1)-\mathrm{O}(7)$ & $142.9(3)$ & $\mathrm{N}(2)-\mathrm{Sb}(1)-\mathrm{O}(7)$ & $67.0(3)$ \\
\hline $\mathrm{O}(1)-\mathrm{Sb}(1)-\mathrm{O}(7)$ & $148.3(3)$ & $\mathrm{O}(13)-\mathrm{Sb}(2)-\mathrm{O}(11)$ & $146.9(3)$ \\
\hline $\mathrm{O}(13)-\mathrm{Sb}(2)-\mathrm{N}(3)$ & $81.3(3)$ & $\mathrm{O}(11)-\mathrm{Sb}(2)-\mathrm{N}(3)$ & $72.4(3)$ \\
\hline $\mathrm{O}(13)-\mathrm{Sb}(2)-\mathrm{N}(4)$ & $75.5(3)$ & $\mathrm{O}(11)-\mathrm{Sb}(2)-\mathrm{N}(4)$ & $79.5(3)$ \\
\hline $\mathrm{N}(3)-\mathrm{Sb}(2)-\mathrm{N}(4)$ & $77.6(3)$ & $\mathrm{O}(13)-\mathrm{Sb}(2)-\mathrm{O}(9)$ & $80.4(3)$ \\
\hline $\mathrm{O}(11)-\mathrm{Sb}(2)-\mathrm{O}(9)$ & $107.0(3)$ & $\mathrm{N}(3)-\mathrm{Sb}(2)-\mathrm{O}(9)$ & $68.3(3)$ \\
\hline $\mathrm{N}(4)-\mathrm{Sb}(2)-\mathrm{O}(9)$ & $140.7(3)$ & $\mathrm{O}(13)-\mathrm{Sb}(2)-\mathrm{O}(15)$ & $96.1(3)$ \\
\hline $\mathrm{O}(11)-\mathrm{Sb}(2)-\mathrm{O}(15)$ & $93.6(3)$ & $\mathrm{N}(3)-\mathrm{Sb}(2)-\mathrm{O}(15)$ & $143.6(3)$ \\
\hline
\end{tabular}

Symmetry transformations used to generate equivalent atoms: \#1 $x-1 / 2,-y, z-1 / 2 ; \# 2 x+1 / 2,-y+1, z-1 / 2 ; \# 3 x-1 / 2,-y+1, z+1 / 2 ; \# 4 x+1 / 2,-y, z+1 / 2$.

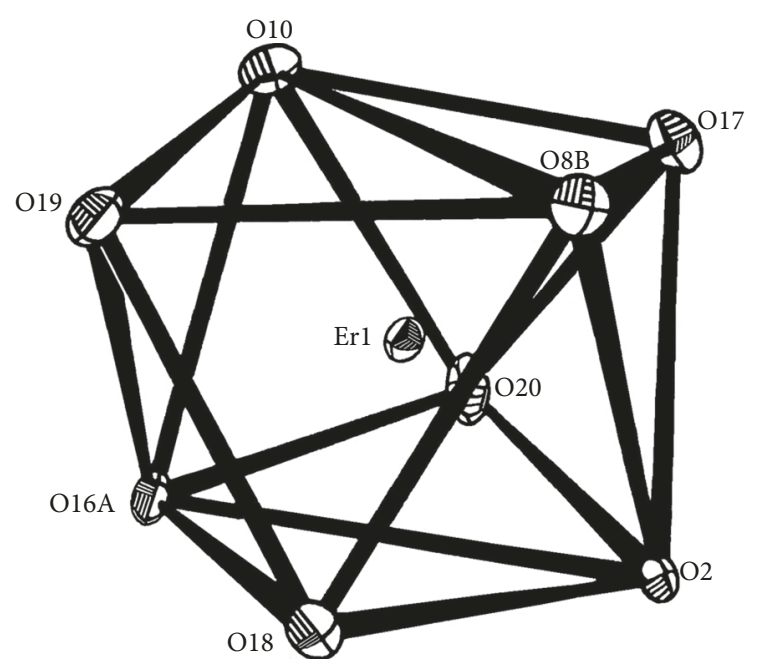

Figure 2: Coordination polyhedron structure of $\operatorname{Er}(\mathrm{III})$. from carboxyl groups and water molecules and also between water molecules strengthen this three-dimensional arrangement.

3.2. FTIR Spectrum. The FTIR spectrum of the title complex is shown in Figure 5. The broad band at about $3426 \mathrm{~cm}^{-1}$ is due to $v(\mathrm{OH})$ vibration of the water molecule. The frequency of the peak is higher than $3400 \mathrm{~cm}^{-1}$ showing that the oxygen atoms of the water molecule are coordinated to the metal ions [51]. The absorption peaks at 1593, 1402, and $1385 \mathrm{~cm}^{-1}$ may be from the asymmetric and symmetric stretching vibration in the carboxyl groups, respectively [52]. It is found that the absorption peak $v_{\mathrm{as}}\left(\mathrm{COO}^{-}\right)$at $1690 \mathrm{~cm}^{-1}$ of $\mathrm{Na}_{2} \mathrm{H}_{2}$ edta is shifted red to $1593 \mathrm{~cm}^{-1}$ and the absorption peak $v_{\mathrm{s}}\left(\mathrm{COO}^{-}\right)$at $1353 \mathrm{~cm}^{-1}$ of $\mathrm{Na}_{2} \mathrm{H}_{2}$ edta is shifted blue to 1402 and $1385 \mathrm{~cm}^{-1}$ in the complex. The difference values $\left[\Delta \nu\left(\nu_{\mathrm{as}}-v_{s}\right)=191\right.$ and $\left.208 \mathrm{~cm}^{-1}\right]$ between the frequencies of the asymmetric and symmetric stretching vibration confirm that the oxygen atoms of carboxylic groups are coordinated 


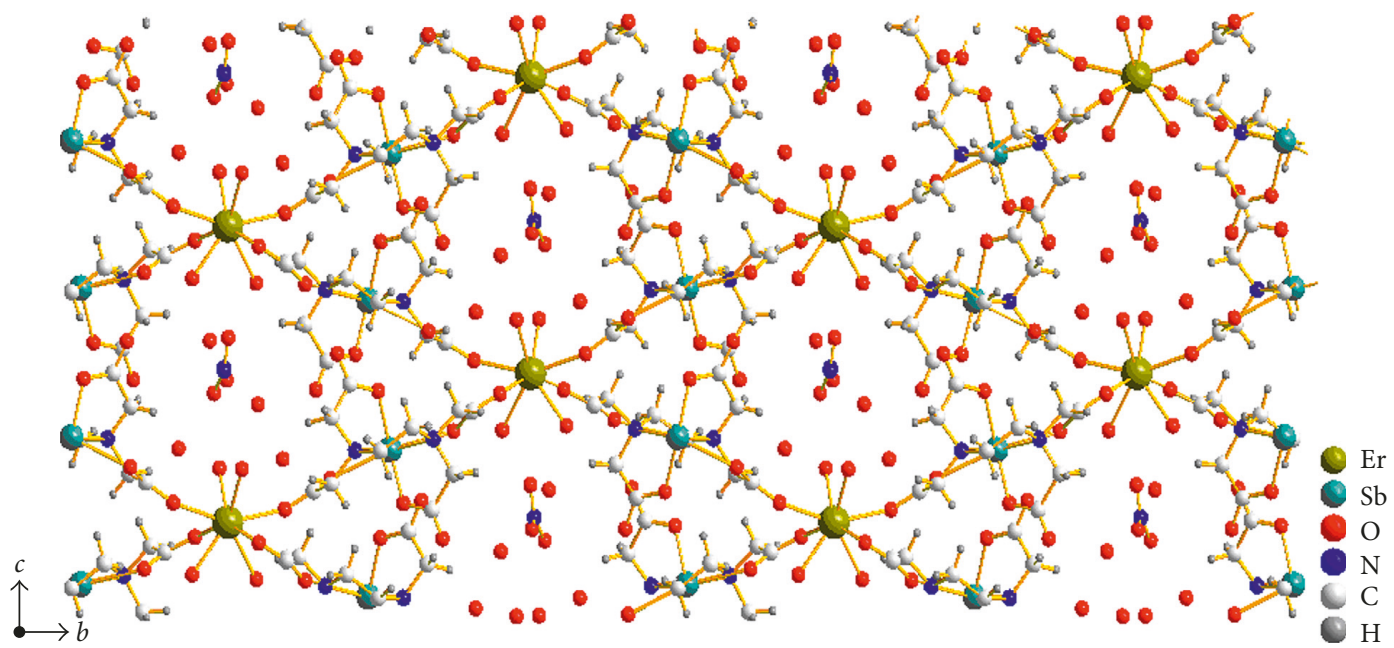

Figure 3: A view of the two-dimensional layer of the complex parallel to the $\left(\begin{array}{lll}1 & 0 & 0\end{array}\right)$ plane.

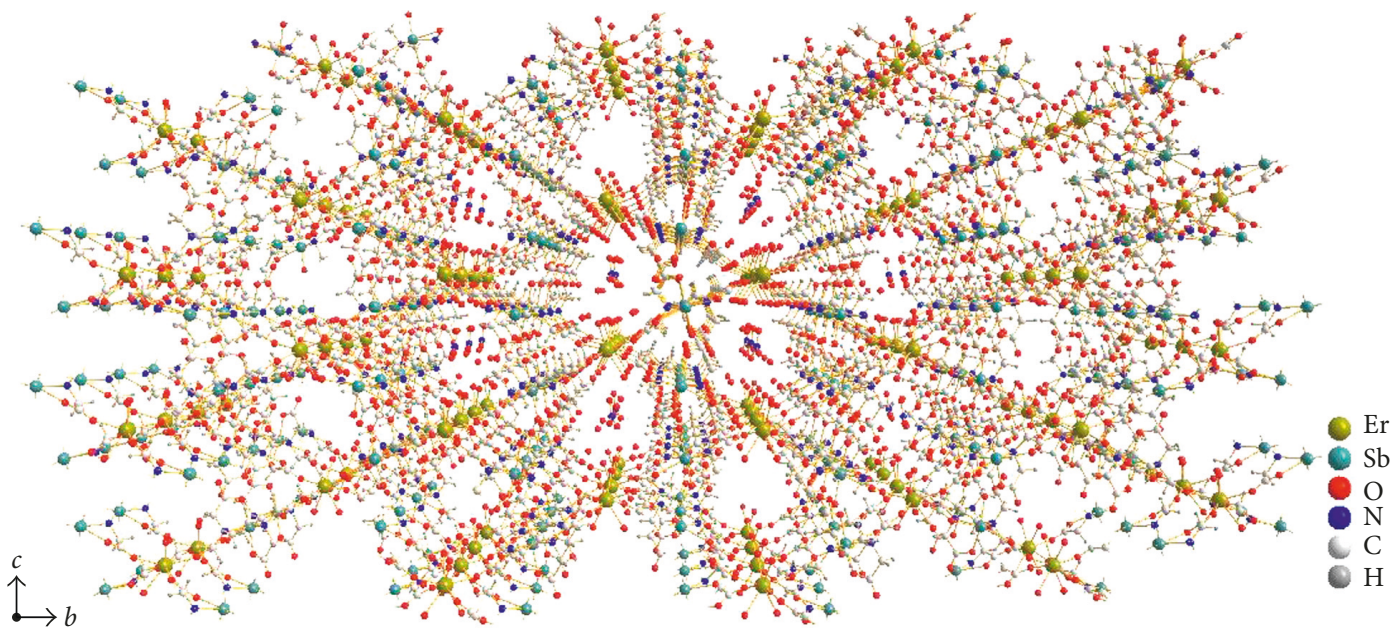

FIgURE 4: Packing diagram of the title complex viewed along the $a$ axis.

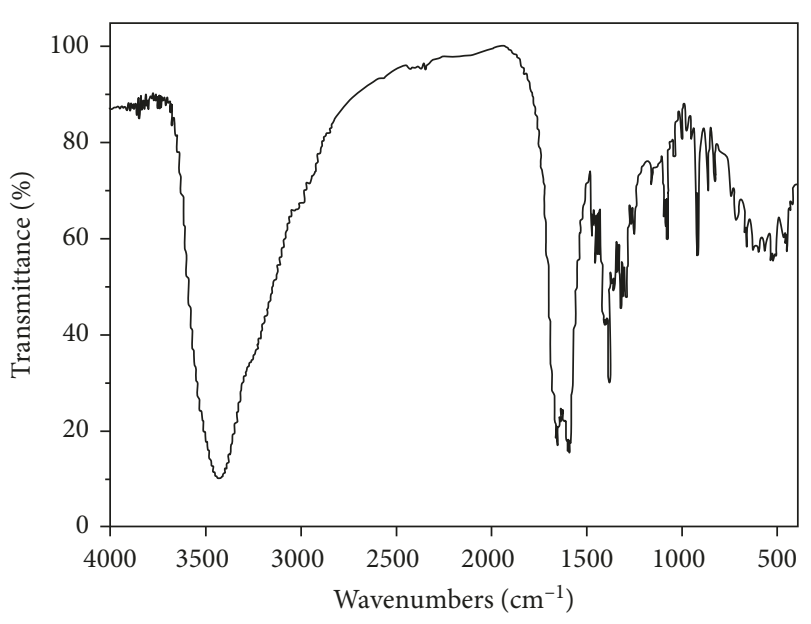

FIGURE 5: FTIR spectrum of the title complex.

to metallic ions by the monodentate mode and bidentate bridge mode in the complex [42], and it is in agreement with the crystal structure. The weaker absorption peaks at about

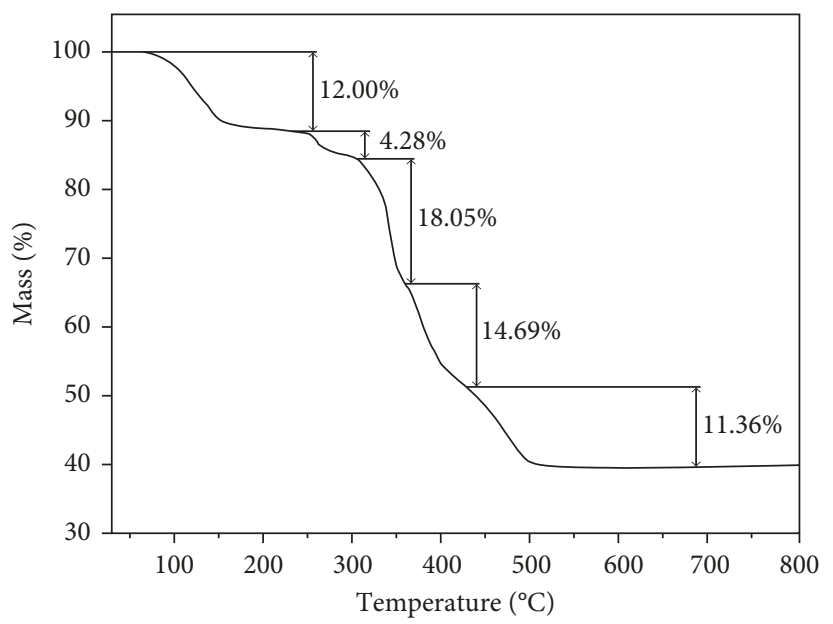

FIgURE 6: TG curve of the title complex.

1356 and $828 \mathrm{~cm}^{-1}$ may be from the stretching vibrations in the free nitrate ion. This indicates that the nitrate ion is not coordinated to the metallic ions. The absorption peaks at 
TABLE 3: Thermal decomposition data of the title complex.

\begin{tabular}{|c|c|c|c|}
\hline \multirow{2}{*}{ Reaction } & \multirow{2}{*}{ Temperature $\left({ }^{\circ} \mathrm{C}\right)$} & \multicolumn{2}{|c|}{ Mass loss (\%) } \\
\hline & & $m_{\exp }$ & $m_{\text {theor }}$ \\
\hline \multicolumn{4}{|l|}{$\left[\mathrm{Sb}_{2}(\mathrm{edta})_{2}-\mu_{4}-\mathrm{Er}\left(\mathrm{H}_{2} \mathrm{O}\right)_{4}\right] \mathrm{NO}_{3} \cdot 4 \mathrm{H}_{2} \mathrm{O}$} \\
\hline$\downarrow-8 \mathrm{H}_{2} \mathrm{O}$ & $70-220$ & 12.00 & 12.08 \\
\hline$\left[\mathrm{Sb}_{2}(\mathrm{edta})_{2} \mathrm{Er}\right] \mathrm{NO}_{3}$ & & & \\
\hline $\begin{array}{l}\downarrow-\mathrm{NO}_{2},-1 / 4 \mathrm{O}_{2} \\
{\left[\mathrm{Sb}_{2}(\text { edta })_{2} \mathrm{Er}\right] \mathrm{O}_{0.5}}\end{array}$ & $220-310$ & 4.28 & 4.53 \\
\hline $\begin{array}{l}\downarrow-2\left(\mathrm{CH}_{2}\right)_{2} \mathrm{NCH}_{2} \mathrm{COO},-1 / 4 \mathrm{O}_{2} \\
(\mathrm{Sb}-\mathrm{Sb})\left[\mathrm{N}\left(\mathrm{CH}_{2} \mathrm{COO}\right)_{3}\right]_{2}(\mathrm{Er}-\mathrm{Er})_{0.5}\end{array}$ & $310-360$ & 18.05 & 17.45 \\
\hline $\begin{array}{l}\downarrow-2 \mathrm{~N}\left(\mathrm{CH}_{2}\right)_{3},-2 \mathrm{CO} \\
(\mathrm{OSbO}-\mathrm{OSbO})(\mathrm{CO})_{4}(\mathrm{OErO}-\mathrm{OErO})_{0.5}\end{array}$ & $360-430$ & 14.69 & 14.09 \\
\hline$\downarrow-4 \mathrm{CO},-3 / 4 \mathrm{O}_{2}$ & $430-510$ & 11.36 & 11.40 \\
\hline $\mathrm{Sb}_{2} \mathrm{O}_{3}+0.5 \mathrm{Er}_{2} \mathrm{O}_{3}$ & & $39.62^{\mathrm{a}}$ & $40.45^{\mathrm{b}}$ \\
\hline
\end{tabular}

${ }^{a}$ The experimental mass percent of the residue in the sample; ${ }^{b}$ the calculated mass percent of the residue in the sample.

1082 and $1039 \mathrm{~cm}^{-1}$ may be from various stretching vibrations of the $\mathrm{C}-\mathrm{N}$ and $\mathrm{C}-\mathrm{C}$ bonds in the edta ${ }^{4-}$ ligand, respectively. In the far-infrared region, the frequency of the stretching vibration of the $\mathrm{Sb}-\mathrm{N}$ bonds is 460 and $448 \mathrm{~cm}^{-1}$, the frequency of the stretching vibration of the $\mathrm{Sb}-\mathrm{O}$ bonds is 434 and $426 \mathrm{~cm}^{-1}$, respectively. It may be reasonable to assign the peaks at 420 and $407 \mathrm{~cm}^{-1}$ to the stretching vibration of the Er-O bonds in the complex [31, 50].

3.3. Thermal Analysis. Studying the thermal decomposition process of complexes is helpful to the understanding of the coordination structure of these complexes [30, 43]. The TG curve of the complex in air atmosphere from room temperature to $800^{\circ} \mathrm{C}$ is shown in Figure 6, and the data of possible thermal decomposition processes are listed in Table 3. The first mass loss of $12.00 \%$ occurs between 70 and $220^{\circ} \mathrm{C}$, corresponding to the gradual loss of the free water molecules and the coordinated water molecules (calculated as $12.08 \%$ for $8 \mathrm{H}_{2} \mathrm{O}$ ). Then, the sample will gradually lose the free nitrate ion at between 220 and $310^{\circ} \mathrm{C}$ and the corresponding mass loss of $4.28 \%$ (calculated as $4.53 \%$ ). Between 310 and $360^{\circ} \mathrm{C}$, two $\left(\mathrm{CH}_{2}\right)_{2} \mathrm{NCH}_{2} \mathrm{COO}$ groups in the complex are oxidized and decomposed, and meanwhile, one quarter oxygen molecules are lost, and the experimental mass loss $(18.05 \%)$ is close to the calculated one $(17.45 \%)$. The fourth step mass loss of the complex from 360 to $430^{\circ} \mathrm{C}$ is $14.69 \%$, corresponding to the mass loss of two $\mathrm{N}\left(\mathrm{CH}_{2}\right)_{3}$ groups and two CO molecules (calculated as 14.09\%) [30]. Upon further heating, the complex is decomposed completely between 430 and $510^{\circ} \mathrm{C}$, and the mass loss of $11.36 \%$ in TG curve corresponds to lose the group of four $\mathrm{CO}$ molecules and threefourths of oxygen molecules (calculated as $11.40 \%$ ). The remaining mass is almost constant until $510^{\circ} \mathrm{C}$, and the final residues of the thermal decomposition of the complex are the mixture of $\mathrm{Sb}_{2} \mathrm{O}_{3}$ and $\mathrm{Er}_{2} \mathrm{O}_{3}$, and the experimental result $(39.62 \%)$ is in agreement with the result of theoretical calculation $(40.45 \%)$.

To check the residue, a certain mass of the complex is placed in an alumina crucible and heated in a muffle furnace at $500^{\circ} \mathrm{C}$ for $2 \mathrm{~h}$. Then the powder X-ray diffraction pattern of the pyrolysis products is recorded. As Figure 7 shows, its characteristic peaks are consistent with the mixture of $\mathrm{Sb}_{2} \mathrm{O}_{3}$

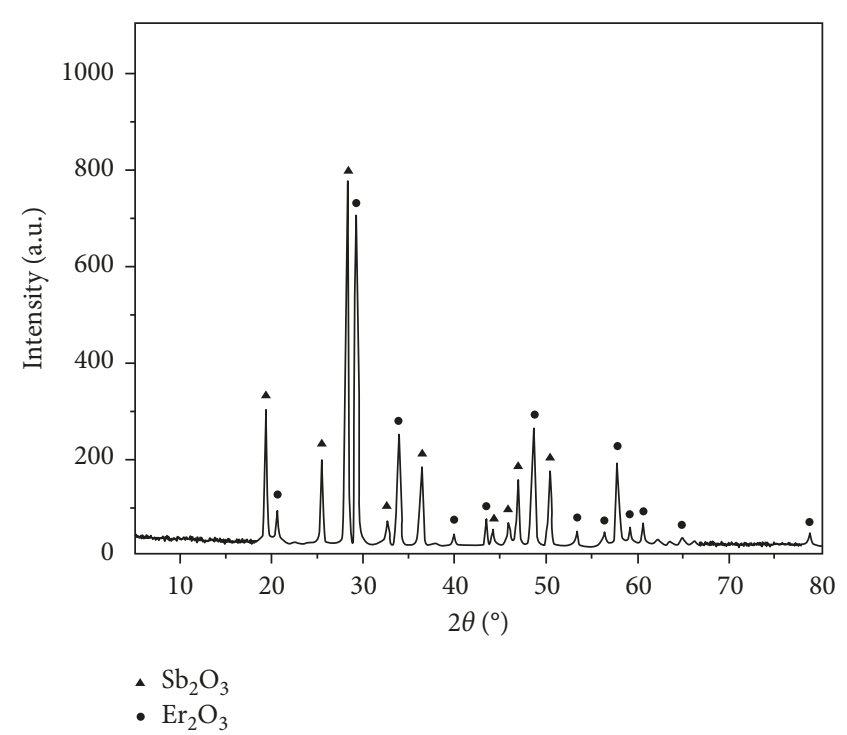

FIGURE 7: XRD pattern of the pyrolysis residue.

(JCPDS no. 71-0383) and $\mathrm{Er}_{2} \mathrm{O}_{3}$ (JCPDS no. 08-0050). Therefore, the pyrolysis residues must be the mixture of $\mathrm{Sb}_{2} \mathrm{O}_{3}$ and $\mathrm{Er}_{2} \mathrm{O}_{3}$.

3.4. Antimicrobial Activity. The culture maintenance and preparation of inoculum were referenced by the literature method [53]. The antimicrobial activities of these compounds were determined qualitatively by agar diffusion method [54]. The inhibition was labeled as the diameter of bacteriostatic circle. A lawn of microorganisms was prepared by pipetting and evenly spreading inoculums $\left(10^{6}-10^{7} \mathrm{CFU} \cdot \mathrm{cm}^{-3}\right)$ onto agar set in petri dishes, using nutrient agar for the bacteria. Furacilinum was dissolved in DMSO, and penicillin, the title complex, and $[\mathrm{Sb}(\mathrm{Hedta})] \cdot 2 \mathrm{H}_{2} \mathrm{O}$ were dissolved in sterilized water. The Oxford cups were sticked on the previously inoculated agar surface and injected solution of the complex $(0.15 \mathrm{~mL})$ under sterile condition. The plates were incubated for $24 \mathrm{~h}$ at $37^{\circ} \mathrm{C}$. The antimicrobial activity was indicated by the presence of clear inhibition zones around the discs. 
TABLe 4: Antibacterial activities of the title complex.

\begin{tabular}{|c|c|c|c|c|c|c|}
\hline \multirow{2}{*}{ Compound } & \multirow{2}{*}{ Concentration $\left(\mathrm{mg} \cdot \mathrm{mL}^{-1}\right)$} & \multicolumn{5}{|c|}{ Inhibition zone diameter $(\mathrm{mm})$} \\
\hline & & S. aureus & E. coli & S. typhi & B. subtilis & S. epidermidis \\
\hline DMSO & - & - & - & - & - & - \\
\hline$[\mathrm{Sb}(\mathrm{Hedta})] \cdot 2 \mathrm{H}_{2} \mathrm{O}$ & 1.0 & 14 & 17 & 13 & 14 & 12 \\
\hline$\left[\mathrm{Sb}_{2}(\text { edta })_{2}-\mu_{4}-\operatorname{Er}\left(\mathrm{H}_{2} \mathrm{O}\right)_{4}\right] \mathrm{NO}_{3} \cdot 4 \mathrm{H}_{2} \mathrm{O}$ & 1.0 & 17 & 26 & 16 & 22 & 16 \\
\hline Penicillin & 1.0 & 15 & 18 & 17 & 19 & 18 \\
\hline Furacilinum & 1.0 & 14 & 23 & 19 & 16 & 20 \\
\hline
\end{tabular}

Preliminary screening for antimicrobial activities of the complex was performed qualitatively using the disc diffusion assay in Table 4. Each of the compounds was tested three times and the average data were recorded. DMF exhibited no effect on the organisms tested. Furacilinum and penicillin were used as standard drugs, and their activities had been compared with the activities of the title complex. The complex yielded clear inhibition zones around the discs. The results show that the complex has significant antibacterial activities against five tested bacteria, and the antibacterial activities of the sequence are Escherichia coli, Bacillus subtilis, Staphylococcus aureus, Salmonella typhi, and Staphylococcus epidermidis, respectively. The complex has good antibacterial activity against Escherichia coli and Bacillus subtilis, and the diameter of inhibition zone of the complex is 26 and $22 \mathrm{~mm}$ with the concentration of $1.0 \mathrm{mg} \cdot \mathrm{mL}^{-1}$. Meanwhile, the complex shows greater or equal activities against bacteria than the penicillin and furacilinum standard drugs.

\section{Conclusions}

The edta-linked heteronuclear complex $\left[\mathrm{Sb}_{2}(\mathrm{edta})_{2}-\mu_{4}\right.$-Er $\left.\left(\mathrm{H}_{2} \mathrm{O}\right)_{4}\right] \mathrm{NO}_{3} \cdot 4 \mathrm{H}_{2} \mathrm{O}$ was synthesized with erbium nitrate and $\left[\mathrm{Sb}(\right.$ Hedta) $] \cdot 2 \mathrm{H}_{2} \mathrm{O}$ as the raw materials, due to easy hydrolysis of antimony ion and its weaker coordination than that of erbium with edta ${ }^{4-}$ ion. The complex was characterized by elemental analyses, FTIR spectrum, X-ray diffraction analyses, and thermogravimetry analysis. The crystal structure of the complex belongs to the monoclinic system and space group $P m$ with cell parameters of $a=7.3790(10) \AA, b=22.116(5) \AA, c=10.661(3) \AA, \beta=90.55$ $(2)^{\circ}$, and $Z=2$. X-ray crystallography analysis reveals that the complex adopts 3-dimensional structures through the weak interactions of antimony and oxygen atoms. The bridging carboxylate- $O, O^{\prime}$ groups of edta ${ }^{4-}$ ions connect with erbium(III) ion and antimony(III) ions. In the complex, the carboxyl oxygen atoms participate in bridging to form diantimony entities and the entities are linked through the carbonyl oxygen atoms to form chains. The metal atoms occupy the space between the chains and are surrounded by the coordinated water molecules, which form hydrogen bonds with the other oxygen atoms of the structure. The complex displays strongly antimicrobial activities on the five tested bacteria.

\section{Conflicts of Interest}

The authors declare that they have no conflicts of interest.

\section{Acknowledgments}

This work was supported by the Scientific Research Funds of Education Department of Sichuan Province (no. 10ZA016) and the Longshan Academic Talent Research Supporting Program of SWUST (no. 17LZX414). The authors are very grateful to Professor Kai-Bei Yu from Chendu Branch of Chinese Academy of Science and Dr. Juan Shen from Southwest University of Science and Technology for the testing and analysis of the single crystal structure.

\section{References}

[1] G.-D. Zou, Z.-P. Wang, Y. Song, B. Hu, and X.-Y. Huang, "Syntheses, structures and photocatalytic properties of five new praseodymium-antimony oxochlorides: from discrete clusters to 3D inorganic-organic hybrid racemic compounds," Dalton Transactions, vol. 43, no. 26, pp. 10064-10073, 2014.

[2] H. P. S. Chauhan and J. Carpenter, "Synthesis, characterization and single crystal X-ray analysis of chlorobis $(N$, $\mathrm{N}$-dimethyldithiocarbamato-S, $S^{\prime}$ )antimony(III)," Journal of Saudi Chemical Society, vol. 19, no. 4, pp. 417-422, 2015.

[3] H. P. S. Chauhan, J. Carpenter, and S. Joshi, "Mixed bis(morpholine-4-dithiocarbamato- $S, S^{\prime}$ )antimony(III) complexes: synthesis, characterization and biological studies," Applied Organometallic Chemistry, vol. 28, no. 8, pp. 605-613, 2014.

[4] M. Kořenková, M. Erben, R. Jambor, A. Růžička, and L. Dostál, "The reactivity of $N, C, N$-intramolecularly coordinated antimony(III) and bismuth(III) oxides with the sterically encumbered organoboronic acid 2,6- $i-\mathrm{Pr}_{2} \mathrm{C}_{6} \mathrm{H}_{3} \mathrm{~B}$ $(\mathrm{OH})_{2} \mathrm{O}$," Journal of Organometallic Chemistry, vol. 772-773, pp. 287-291, 2014.

[5] H. P. S. Chauhan, S. Joshi, and J. Carpenter, "Synthetic, spectral, thermal and powder X-ray diffraction studies of bis $\left(O\right.$-alkyldithiocarbonato- $\left.S, S^{\prime}\right)$ antimony(III) dialkyldithiocarbamates," Spectrochimica Acta Part A, vol. 136, pp. 1626-1634, 2015.

[6] H. D. Yin and J. Zhai, "Synthesis, characterizations and crystal structures of antimony(III) complexes with nitrogencontaining ligands," Inorganica Chimica Acta, vol. 362, no. 2, pp. 339-345, 2009.

[7] D. C. Reis, M. C. X. Pinto, E. M. Souza-Fagundes et al., "Investigation on the pharmacological profile of antimony(III) complexes with hydroxyquinoline derivatives: antitrypanosomal activity and cytotoxicity against human leukemia cell lines," BioMetals, vol. 24, no. 4, pp. 595-601, 2011.

[8] Z.-P. Zhang, G.-Q. Zhong, and Q.-Y. Jiang, "Biological activities of the complexes of arsenic, antimony and bismuth," Progress in Chemistry, vol. 20, no. 9, pp. 1315-1323, 2008.

[9] J. A. Lessa, D. C. Reis, I. C. Mendes et al., "Antimony(III) complexes with pyridine-derived thiosemicarbazones: 
structural studies and investigation on the antitrypanosomal activity," Polyhedron, vol. 30, no. 2, pp. 372-380, 2011.

[10] E. H. Lizarazo-Jaimes, P. G. Reis, F. M. Bezerra et al., "Complexes of different nitrogen donor heterocyclic ligands with $\mathrm{SbCl}_{3}$ and $\mathrm{PhSbCl}_{2}$ as potential antileishmanial agents against $\mathrm{Sb}^{\mathrm{III}}$-sensitive and -resistant parasites," Journal of Inorganic Biochemistry, vol. 132, pp. 30-36, 2014.

[11] J. Shen, B. Jin, Q.-Y. Jiang, G.-Q. Zhong, Y.-M. Hu, and J.-C. Huo, "Synthesis, structures, luminescent and magnetic properties of heterometallic 5p-4f compounds with ethylenediaminetetraacetate," Zeitschrift für anorganische und allgemeine Chemie, vol. 639, no. 1, pp. 89-95, 2013.

[12] M. N. Rocha, P. M. Nogueira, C. Demicheli et al., "Cytotoxicity and in vitro antileishmanial activity of antimony(V), bismuth(V), and tin(IV) complexes of lapachol," Bioinorganic Chemistry and Applications, vol. 2013, Article ID 961783, 7 pages, 2013.

[13] L. Dawara and R. V. Singh, "Microwave-assisted synthesis, characterization, antimicrobial, and pesticidal activity of bismuth and antimony complexes with coumarin-based ligands," Journal of Coordination Chemistry, vol. 64, no. 6, pp. 931-941, 2011.

[14] I. I. Ozturk, S. Filimonova, S. K. Hadjikakou et al., "Structural motifs and biological studies of new antimony(III) iodide complexes with thiones," Inorganic Chemistry, vol. 49, no. 2, pp. 488-501, 2010.

[15] I. I. Ozturk, S. K. Hadjikakou, N. Hadjiliadis et al., "New antimony(III) bromide complexes with thioamides: synthesis, characterization, and cytostatic properties," Inorganic Chemistry, vol. 48, no. 5, pp. 2233-2245, 2009.

[16] H. P. S. Chauhan, J. Carpenter, and S. Joshi, "Synthetic aspects, spectral, thermal studies and antimicrobial screening on bis $\left(N, N\right.$-dimethyldithiocarbamato- $\left.S, S^{\prime}\right)$ antimony(III) complexes with oxo or thio donor ligands," Spectrochimica Acta Part A, vol. 130, pp. 230-237, 2014.

[17] E. D. L. Piló, A. A. Recio-Despaigne, J. G. D. Silva, I. P. Ferreira, J. A. Takahashi, and H. Beraldo, "Effect of coordination to antimony(III) on the antifungal activity of 2-acetylpyridine- and 2-benzoylpyridine-derived hydrazones," Polyhedron, vol. 97, pp. 30-38, 2015.

[18] T. Tunç, M. S. Karacan, H. Ertabaklar, M. Sarı, N. Karacan, and O. Büyükgüngör, "Antimony(III) complexes with 2-amino-4,6-dimethoxypyrimidines: synthesis, characterization and biological evaluation," Journal of Photochemistry and Photobiology B, vol. 153, pp. 206-214, 2015.

[19] H. P. S. Chauhan, A. Bakshi, and S. Bhatiya, "Synthesis, spectroscopic characterization and antibacterial activity of antimony(III) bis(dialkyldithiocarbamato)alkyldithiocarbonates," Spectrochimica Acta Part A, vol. 81, no. 1, pp. 417-423, 2011.

[20] O. S. Urgut, I. I. Ozturk, C. N. Banti et al., "Addition of tetraethylthiuram disulfide to antimony(III) iodide; synthesis, characterization and biological activity," Inorganica Chimica Acta, vol. 443, pp. 141-150, 2016.

[21] I. I. Ozturk, C. N. Banti, M. J. Manos et al., "Synthesis, characterization and biological studies of new antimony(III) halide complexes with $\omega$-thiocaprolactam," Journal of Inorganic Biochemistry, vol. 109, pp. 57-65, 2012.

[22] D. C. Reis, M. C. X. Pinto, E. M. Souza-Fagundes, S. M. S. V. Wardell, J. L. Wardell, and H. Beraldo, "Antimony (III) complexes with 2-benzoylpyridine-derived thiosemicarbazones: cytotoxicity against human leukemia cell lines," European Journal of Medicinal Chemistry, vol. 45, no. 9, pp. 3904-3910, 2010.
[23] I. I. Ozturk, O. S. Urgut, C. N. Banti et al., "Synthesis, structural characterization and cytotoxicity of the antimony (III) chloride complex with $\mathrm{N}, \mathrm{N}$-dicyclohexyldithiooxamide," Polyhedron, vol. 52, pp. 1403-1410, 2013.

[24] I. I. Ozturk, C. N. Banti, N. Kourkoumelis et al., "Synthesis, characterization and biological activity of antimony(III) or bismuth(III) chloride complexes with dithiocarbamate ligands derived from thiuram degradation," Polyhedron, vol. 67, pp. 89-103, 2014.

[25] I. I. Ozturk, O. S. Urgut, C. N. Banti et al., "Synthesis, structural characterization and cytostatic properties of $N$, $\mathrm{N}$-dicyclohexyldithiooxamide complexes of antimony(III) halides (SbX 3 , X: Br or I)," Polyhedron, vol. 70, pp. 172-179, 2014.

[26] A. Han, I. I. Ozturk, C. N. Banti et al., "Antimony(III) halide compounds of thioureas: structures and biological activity," Polyhedron, vol. 79, pp. 151-160, 2014.

[27] J. J. Borras-Almenar and E. Coronado, "Single crystal EPR study of the bimetallic ferrimagnetic chain $\mathrm{MnCu}(\mathrm{EDTA})$. $6 \mathrm{H}_{2} \mathrm{O}$," Inorganica Chimica Acta, vol. 207, no. 1, pp. 105-109, 1993.

[28] E. Coronado, M. Drillon, P. R. Nugteren, L. J. Jongh, D. Beltran, and R. Georges, "Low-temperature investigation of the ferrimagnetic chains $\mathrm{MnM}^{\prime}(\mathrm{EDTA}) \cdot 6 \mathrm{H}_{2} \mathrm{O}\left[\mathrm{M}^{\prime}=\right.$ cobalt, nickel, and copper(II)]: thermaland magnetic properties," Journal of the American Chemical Society, vol. 111, no. 11, pp. 3874-3880, 1989.

[29] F. Sapina, E. Coronado, D. Beltran, and R. Burriel, "From 1-D to 3-D ferrimagnets in the EDTA family: magnetic characterization of thetetrahydrate series $\mathrm{MtM}\left(\mathrm{M}^{\prime} \text { EDTA }\right)_{2} \cdot 4 \mathrm{H}_{2} \mathrm{O}$ [Mt, M, $\mathrm{M}^{\prime}=$ cobalt(II), nickel(II), zinc(II)]," Journal of the American Chemical Society, vol. 113, no. 21, pp. 7940-7944, 1991.

[30] G. Q. Zhong, J. Shen, Q. Y. Jiang, Y. Q. Jia, M. J. Chen, and Z. P. Zhang, "Synthesis, characterization and thermal decomposition of $\mathrm{Sb}^{\mathrm{III}}-\mathrm{M}-\mathrm{Sb}^{\mathrm{III}}$ type trinuclear complexes of ethylenediamine- $\mathrm{N}, \mathrm{N}, \mathrm{N}^{\prime}, \mathrm{N}^{\prime}$-tetraacetate (M: Co(II), La(III), $\mathrm{Nd}(\mathrm{III}), \mathrm{Dy}(\mathrm{III}))$," Journal of Thermal Analysis and Calorimetry, vol. 92, no. 2, pp. 607-616, 2008.

[31] J. Shen, Q.-Y. Jiang, G.-Q. Zhong, Y.-Q. Jia, and K.-B. Yu, "Synthesis, crystal structure and thermal decomposition of a novel 3D heterometallic $\mathrm{Sb}(\mathrm{III})-\mathrm{Pr}(\mathrm{III})$ complex $\left[\mathrm{Sb}_{2}-\mu_{4^{-}}\right.$ (EDTA $\left.)_{2} \operatorname{Pr}\left(\mathrm{H}_{2} \mathrm{O}\right)_{5}\right]_{\mathrm{NO}_{3}} \cdot 4 \mathrm{H}_{2} \mathrm{O}$," Acta Chimica Sinica, vol. 65, no. 16, pp. 1588-1592, 2007.

[32] V. Stavila, R. L. Davidovich, A. Gulea, and K. H. Whitmire, "Bismuth(III) complexes with animopolycarboxylate and polyamino-polycarboxylate ligands: chemistry and structure," Coordination Chemistry Reviews, vol. 250, no. 21-22, pp. 2782-2810, 2006.

[33] Q.-Y. Jiang, H.-Q. Deng, G.-Q. Zhong, P. He, and N.-H. Hu, "Synthesis, crystal structure and thermal stability of 3D heterometallic Bi(III)-Pr(III) polymer complex," Chemical Journal of Chinese Universities, vol. 29, no. 12, pp. 2521-2524, 2008.

[34] G. Q. Zhong, S. R. Luan, P. Wang, Y. C. Guo, Y. R. Chen, and Y. Q. Jia, "Synthesis, characterization and thermal decomposition of thiourea complexes of antimony and bismuth triiodide," Journal of Thermal Analysis and Calorimetry, vol. 86, no. 3, pp. 775-781, 2006.

[35] G.-Q. Zhong, Y.-C. Guo, Y.-R. Chen, X.-S. Zang, and S.-R. Luan, "Synthesis and crystal structure of the complex of thioglycollic acid and trivalent antimony ion," Acta Chimica Sinica, vol. 59, no. 10, pp. 1599-1603, 2001.

[36] S. Smola, N. Rusakova, and Y. U. Korovin, "New luminescent heteronuclear $\mathrm{Ln}(\mathrm{III})-\mathrm{Bi}(\mathrm{III})$ complexes $(\mathrm{Ln}=\mathrm{Nd}, \mathrm{Eu}, \mathrm{Tb}$, 
Yb) based on aminopolycarboxylic acids," Journal of Coordination Chemistry, vol. 64, no. 5, pp. 863-874, 2011.

[37] H. Ajaz, S. Hussain, M. Altaf et al., "Synthesis and characterization of antimony(III) complexes of thioamides, and crystal structure of $\left\{\left[\mathrm{Sb}(\operatorname{Imt})_{2} \mathrm{Cl}_{2}\right]_{2}\left(\mu_{2}\right.\right.$-Imt $\left.)\right\} \mathrm{Cl}_{2}(\mathrm{Imt}=\mathrm{Imi}-$ dazolidine-2-thione)," Chinese Journal of Chemistry, vol. 29, no. 2, pp. 254-258, 2011.

[38] Y.-Z. Li, R. Ganguly, and W. K. Leong, "Oxidative addition of halogen across an Os-Os or Os-Sb bond: formation of fivemembered osmium-antimony carbonyl rings," Journal of Organometallic Chemistry, vol. 811, pp. 66-73, 2016.

[39] H. Choujaa, A. L. Johnson, G. Kociok-Köhn, and K. C. Molloy, "The synthesis of a novel heterobimetallic amidotungstenantimony complex," Polyhedron, vol. 29, no. 6, pp. 1607-1611, 2010.

[40] Y.-Z. Li and W. K. Leong, "Raft-like osmium- and rutheniumantimony carbonyl clusters," Journal of Organometallic Chemistry, vol. 812, pp. 217-225, 2016.

[41] J. Shen, B. Jin, Q.-Y. Jiang, G.-Q. Zhong, Y.-M. Hu, and J.-C. Huo, "Edta-linked 5p-4f trinuclear heterometallic complex: syntheses, X-ray structure and luminescent properties," Journal of Coordination Chemistry, vol. 65, no. 17, pp. 3040-3049, 2012.

[42] G.-Q. Zhong, J. Shen, Q.-Y. Jiang, and K.-B. Yu, "Synthesis and structural determination of a novel heterometallic complex $\left[\mathrm{Sb}_{2}(\text { edta })_{2}-\mu_{4}-\mathrm{Co}\left(\mathrm{H}_{2} \mathrm{O}\right)_{2}\right] \cdot 5.15 \mathrm{H}_{2} \mathrm{O}$," Chinese Journal of Chemistry, vol. 29, no. 12, pp. 2650-2654, 2011.

[43] J. Shen, B. Jin, Q.-Y. Jiang, G.-Q. Zhong, Y.-M. Hu, and J.-C. Huo, "Synthesis, characterization, and magnetic properties of heterometallic trinuclear complex with $\mathrm{Sb}$ (III) and Ho(III)," Inorganica Chimica Acta, vol. 385, pp. 158-163, 2012.

[44] Q.-Y. Jiang, H.-Q. Deng, P. He, G.-Q. Zhong, and K.-B. Yu, "Sm(III)-Bi(III) heterometallic complexes with aminopolycarboxylate ligand: structure, thermal stability and spectral property," Chinese Journal of Chemistry, vol. 29, no. 12, pp. 2637-2642, 2011.

[45] Q.-Y. Jiang, H.-Q. Deng, Y.-M. Hu, J. Shen, G.-Q. Zhong, and N.-H. Hu, "Crystal structure and thermal decomposition of a $2 \mathrm{D}$ heterometallic coordination polymer $\{[\mathrm{NdBi}(\mathrm{cydta})$ $\left.\left.\left(\mathrm{NO}_{3}\right)_{2}\left(\mathrm{H}_{2} \mathrm{O}\right)_{4}\right] \cdot 2.5 \mathrm{H}_{2} \mathrm{O}\right\}_{n}$," Acta Chimica Sinica, vol. 66, no. 12, pp. 1429-1434, 2008.

[46] D. Li and G.-Q. Zhong, "Synthesis and crystal structure of the bioinorganic complex [Sb(Hedta) $\left.2 \mathrm{H}_{2} \mathrm{O}\right]$," Bioinorganic Chemistry and Applications, vol. 2014, Article ID 461605, 7 pages, 2014.

[47] G. M. Sheldrick, "A short history of SHELX," Acta Crystallographica Section A, vol. 64, no. 1, pp. 112-122, 2008.

[48] W. J. Geary, "The use of conductivity measurements in organic solvents for the characterisation of coordination compounds," Coordination Chemistry Reviews, vol. 7, no. 1, pp. 81-122, 1971.

[49] B. Marrot, C. Brouca-Cabarrecq, and A. Mosset, " $\left[\mathrm{CaSb}_{2}(\mathrm{EDTA})_{2}\left(\mathrm{H}_{2} \mathrm{O}\right)_{8}\right]_{n}$ : synthesis, crystal structure, and thermal behavior," Journal of Chemical Crystallography, vol. 28, no. 6, pp. 447-452, 1998.

[50] J. Wang, X.-D. Zhang, Z.-R. Liu, and W.-G. Jia, "Synthesis and structural determination of binuclear nine-coordinate $(\mathrm{NH} 4)_{4}\left[\mathrm{Yb}_{2}(\mathrm{dtpa})_{2}\right] \cdot 9 \mathrm{H}_{2} \mathrm{O}$," Journal of Molecular Structure, vol. 613, no. 1-3, pp. 189-193, 2002.

[51] K. Nakamoto, Infrared and Raman Spectra of Inorganic and Coordination Compounds, John Wiley \& Sons Inc., New York, NY, USA, 6th edition, 2009.

[52] H.-P. Xiao, S. Aghabeygi, W.-B. Zhang et al., "A new $\mathrm{Zn}^{\mathrm{II}}$ twodimensional coordination polymer, $\left\{\left[\operatorname{Zn}\left(\mu-4,4^{\prime}\right.\right.\right.$-bipy $)(1,4-\mathrm{ndc})$
$\left.\left.\left(\mathrm{H}_{2} \mathrm{O}\right)_{2}\right] \cdot\left(\mathrm{H}_{2} \mathrm{O}\right)\right\}_{n}\left(4,4^{\prime}\right.$-bipy $=4,4^{\prime}$-bipyridine and 1,4-ndc $=$ 1,4-naphthalenedicarboxylate)," Journal of Coordination Chemistry, vol. 61, no. 22, pp. 3679-3686, 2008.

[53] Y.-C. Guo, Y.-Q. Feng, Z.-P. Qiao, S.-Y. Chen, and S.-Z. Huang, "Syntheses, crystal structures and antibacterial activities of dithiocarbamate complexes $\left[\mathrm{M}\left(\mathrm{MeBnNCS}_{2}\right)_{3}\right]$, $\mathrm{M}=\mathrm{Sb}(\mathrm{III}), \mathrm{Bi}(\mathrm{III})$, , Chinese Journal of Inorganic Chemistry, vol. 30, no. 5, pp. 1031-1037, 2014.

[54] A. C. Ekennia, D. C. Onwudiwe, L. O. Olasunkanmi, A. A. Osowole, and E. E. Ebenso, "Synthesis, DFT calculation, and antimicrobial studies of novel $\mathrm{Zn}(\mathrm{II}), \mathrm{Co}(\mathrm{II}), \mathrm{Cu}(\mathrm{II})$, and $\mathrm{Mn}$ (II) heteroleptic complexes containing benzoylacetone and dithiocarbamate," Bioinorganic Chemistry and Applications, vol. 2015, Article ID 789063, 12 pages, 2015. 

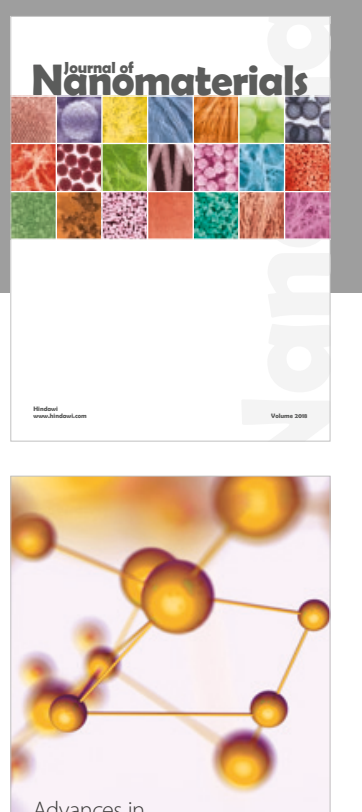

Physical Chemistry
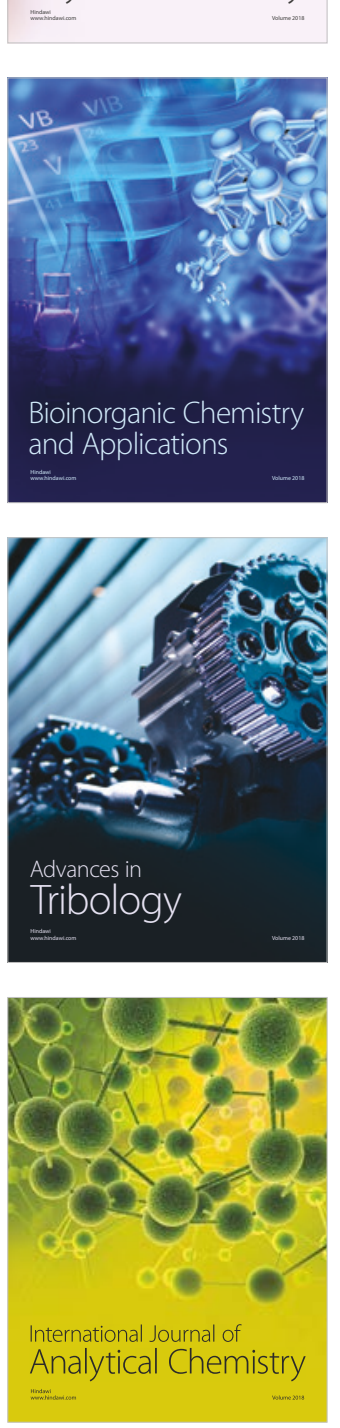

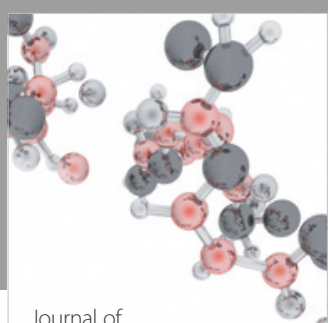

Analytical Methods

in Chemistry

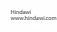

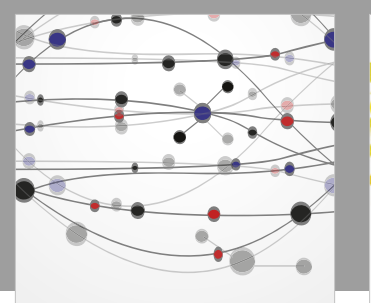

The Scientific World Journal

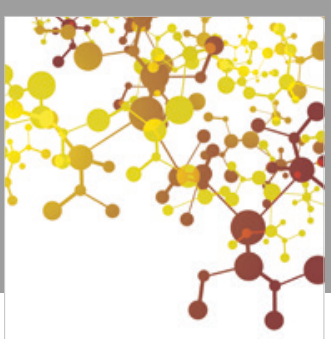

Journal of

Applied Chemistry
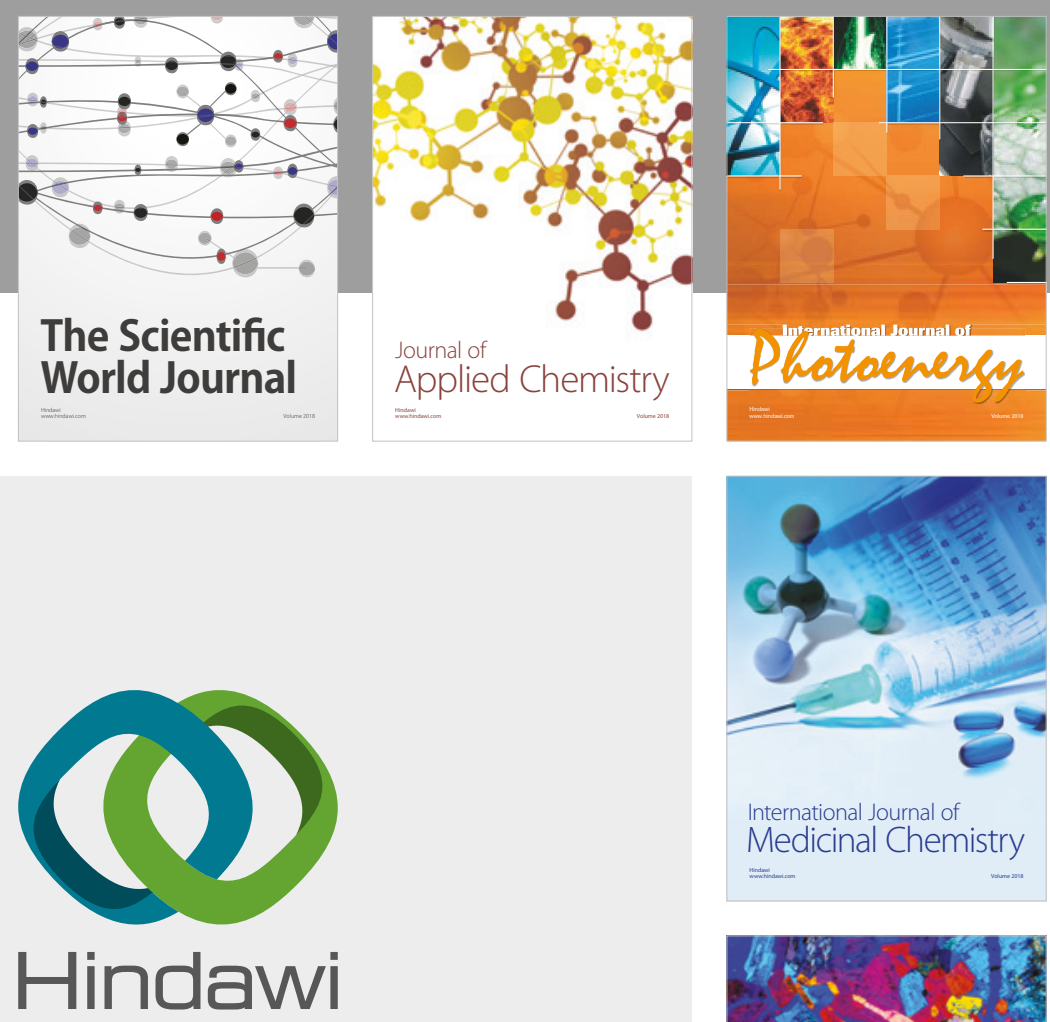

Submit your manuscripts at

www.hindawi.com
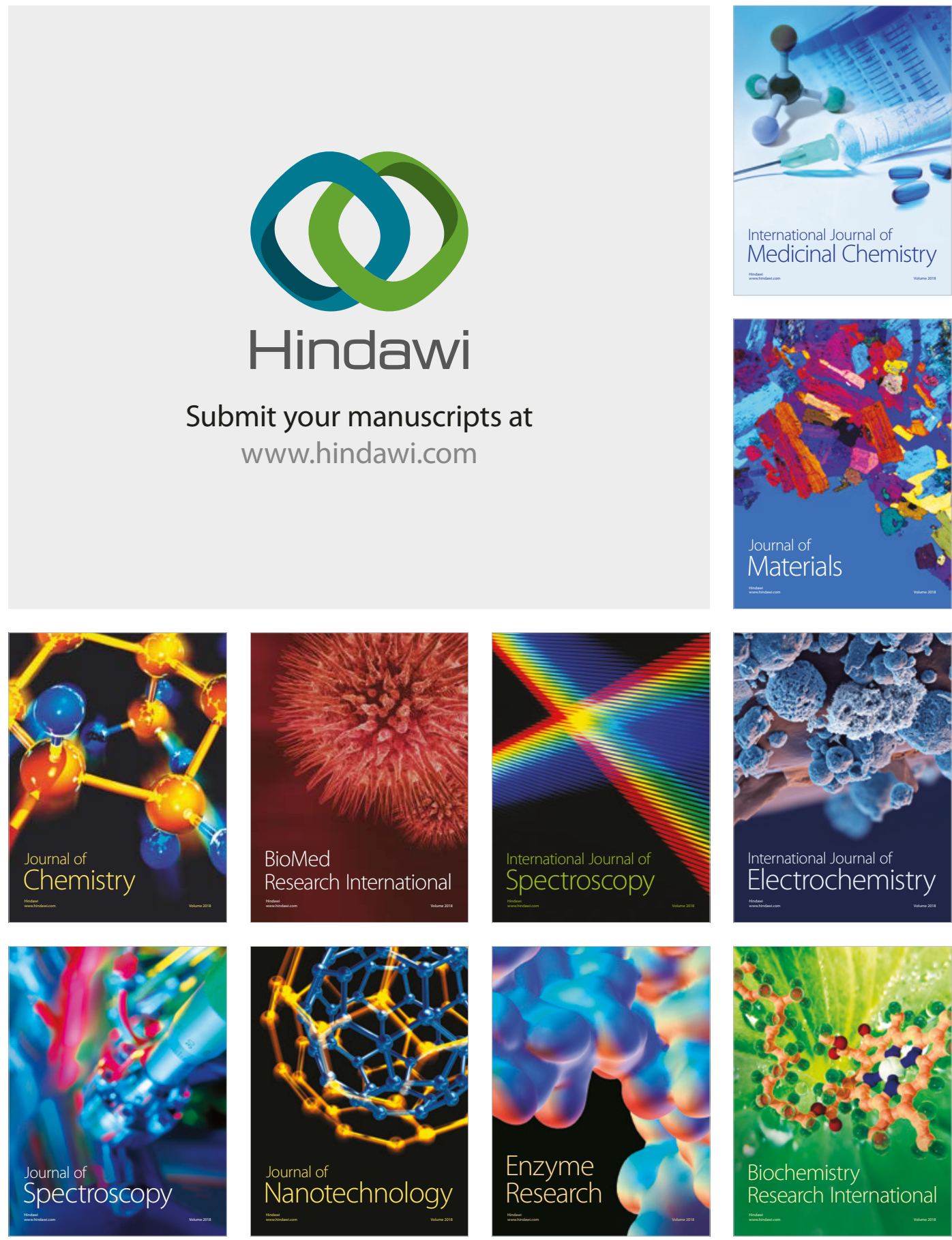
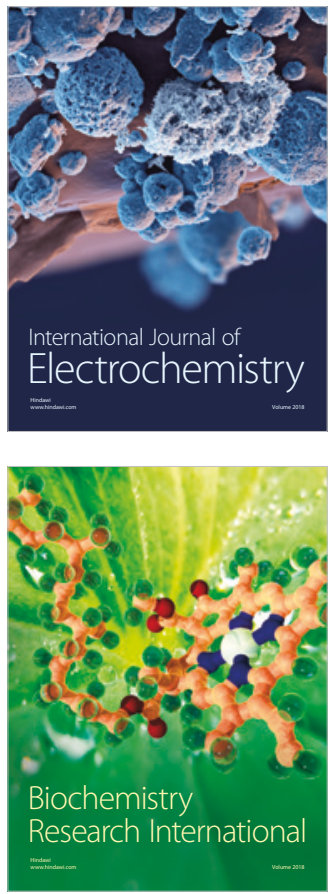